\title{
Climate and land use effects on forest cover in the Bernese Alps during the 20th century
}

\section{Tobias Providoli, Bern, Nikolaus J. Kuhn, Basel}

\section{Introduction}

The transition between a closed forest cover and open shrub or grassland in polar and alpine regions is commonly associated with the so-called «tree line». According to KöRNER (2003), tree cover expands to the temperature isotherm of 5.5 to $7.5^{\circ} \mathrm{C}$. Below this temperature, life for a tree is not possible (KöRNER 2003; WIESER \& TAUSz 2007). In reality, local micro-climatic as well as spatially and temporarily variable edaphic conditions lead to the development of a zone of transition between forest and grass or shrub cover which is referred to as the borderline ecotone. As a consequence of global warming, both the altitudinal and latitudinal upward movement of borderline ecotones has been postulated (e.g. Walther et al. 2005). Such movements of vegetation borderline ecotones have taken place frequently during the Holocene (e.g. Kearney \& LuCKMANN (1983). Consequently, recent observations of increasing elevations of tree cover have been attributed to the current trend in global warming. For example, VAN DER MeER et al. (2004) observed a rising of the forest cover by 100 meters during 300 years in Southern Ural. Most studies therefore agree that global warming will favor the rising of altitudinal and polar forest lines (e.g. Anisimov et al. 2007). However, the rate of change and the extent of the future forest cover varies on a local and regional scale (e.g. HoltMeier \& Broll 2007). Furthermore, the simple temperature-elevation/ latitude relationship ignores the interaction of surface processes and the effects of land use on forest cover, such as land use or the ecologic disturbance regime (e.g. Macias Fauria et al. 2011). The aim of this study was therefore to attempt an identification of the proportion of forest cover change that can be attributed directly to climate global warming in an intensely used central alpine region.

\section{Study area}

The study area is situated in the northern main ranges of the Alps in the eastern Bernese Oberland in Switzerland, covering the territory of the community of Grindelwald (46 $377^{\prime} 33^{\prime \prime} \mathrm{N}$ and $\left.8^{\circ} 02^{\prime} 00^{\prime \prime} \mathrm{E}\right)$ (Fig. 1). The climate in the northern Alps is humid (annual precipitation in Grindelwald $1251 \mathrm{~mm}$ ) with a moderate annual average temperature of $5.9^{\circ} \mathrm{C}$ in Grindelwald
(1034 $\mathrm{m}$ a.s.1.) and $-7.9^{\circ} \mathrm{C}$ on the Jungfraujoch $(3471 \mathrm{~m}$ a.s.l.) (KienHolz 1977; STAMPFLI 1995). Global warming in the past century has affected the study area disproportionally. Worldwide, temperatures mounted in the last century by $0.6{ }^{\circ} \mathrm{C}$ (Dobbertin \& Giuggiola 2006; Intergovernmental Panel on Climate Change - IPCC 2007). In Switzerland, the land surface temperature has increased by $0.86{ }^{\circ} \mathrm{C}$ since the beginning of the 19th century (MeteoSwiss 2011; NorTh et al. 2007). The climate stations in Meiringen and on the Jungfraujoch, both near to Grindelwald, show a similar increase of $0.9^{\circ} \mathrm{C}$ for the decadal mean air temperature (Meteo-Swiss 2010).

The forest borderline ecotone in the study area ranges from 1900 to $2100 \mathrm{~m}$ a.s.l. depending on the microclimatic conditions. Tree vegetation is dominated by Picea abies, but there are also significant proportions of Pinus cembra, Larix decidua and Pinus mugo (LOTTER et al. 2006). The vegetation of the study area is strongly influenced by human activities such as agriculture or tourism. In the last decades this has led to both an increase in forest cover on abandoned grazing land, but also to a decline due to open roads and skiing tracks (BAur et al. 2005; EwALD \& Klaus 2010; GeHRIG-FASEL et al. 2007; GelLrich et al. 2007). In Grindelwald, the agricultural sector also lost a share in land use to tourism, but the traditional alpine grazing area has largely been conserved (NÄGELI 1986; TIEFENBACH \& MORDASINI 2006).

\section{GIS analysis of forest cover changes}

The expansion of a forest proceeds slowly and is difficult to observe directly. Comparing a time series of maps and photographs offers a good opportunity to reconstruct changes in surface conditions (e.g. EWALD \& Klaus 2010; Meusburger \& Alewell 2009). For this study, the forest cover change since the end of the 19th century was examined because the oldest reliably geo-referenced map of Grindelwald, the Siegfried map, was published in 1899. The Siegfried maps (Fig. 2) have primarily been printed in black (situation, scripture, cliff design and forest), brown (contour lines) and blue (waters). The forest cover documented in the Siegfried map was digitized using ArcGIS. A shapefile for the 2005 forest cover map was generated based on the digital landscape model of Switzerland (VEKTOR25) accessed through the Office for Geoinformation of the Kanton Bern. Both data sources distinguish between 

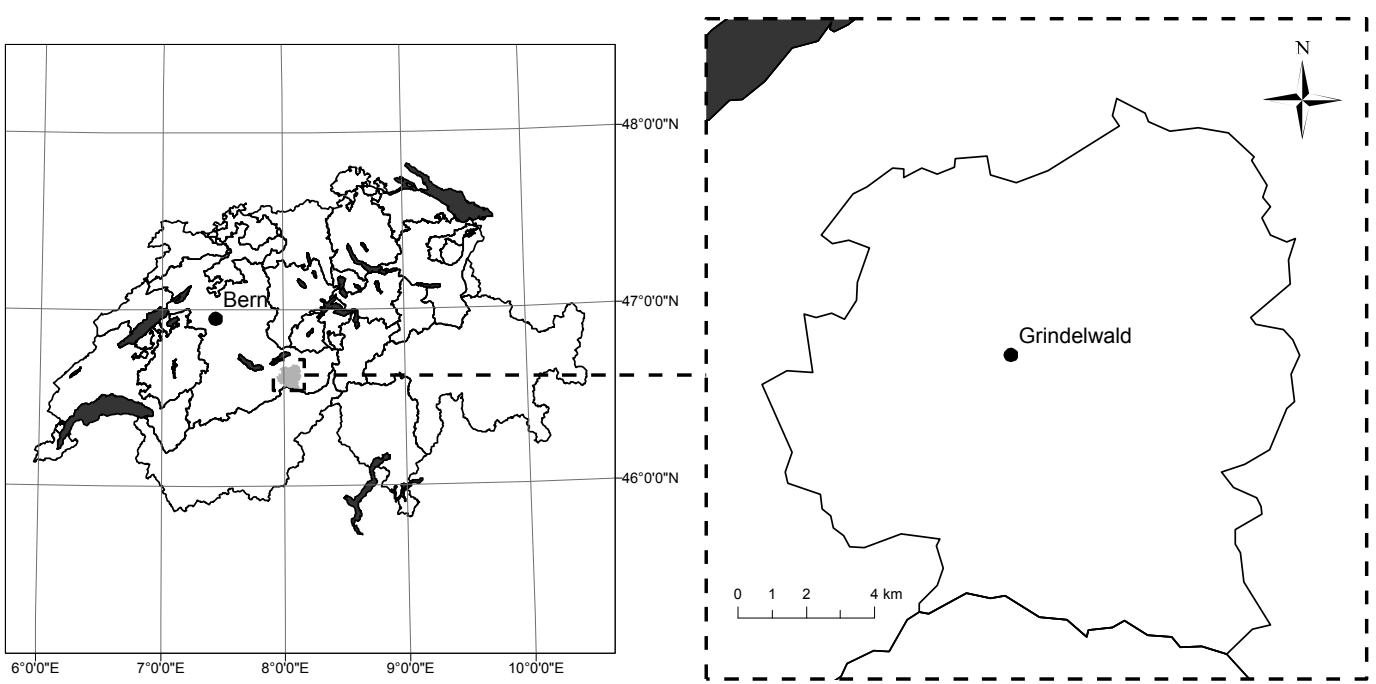

Fig. 1: Site Grindelwald (Canton of Bern, Switzerland)

Standort Grindelwald (Kanton Bern, Schweiz)

Site de Grindelwald (Canton de Berne, Suisse)

Source: Data @ GADM - Global administrative areas, access: 15.7.2011; cartography: T. ProvidoLI
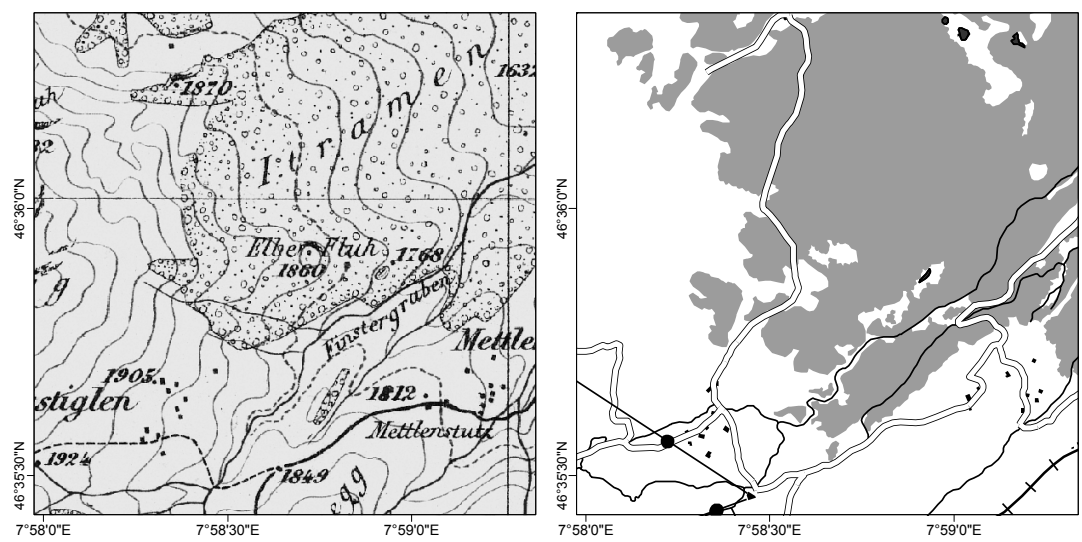

\section{Legend}

m stream network

$=$ streets

+ railway

- - aerial passenger line

* forest cover 2005

buildings

lakes
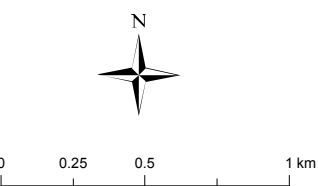

Fig. 2: Section of the Siegfried map sheet No. 396 Grindelwald and VEKTOR25

Ausschnitt der Siegfriedkarte Blatt Nr. 396 Grindelwald und VEKTOR25

Extrait de la carte Siegfried, feuille No. 396, Grindelwald et VEKTOR25

Source: Data (C) Office for Geoinformation of the Canton of Bern, 15.7.2011; cartography: T. Providoli

closed and open forest. In this study, only closed forest cover was examined according to the distinction between closed forest and the transitional character of the borderline ecotone. For the calculations of forest cover change the shapefiles of 1899 and 2005 were compared using ArcGIS. The areal extent of forest expansion or decline was calculated by importing the shapefiles showing a change in cover into a geodatabase. Geodatabases can be used to collect shapefiles, transform them into feature classes and make several 


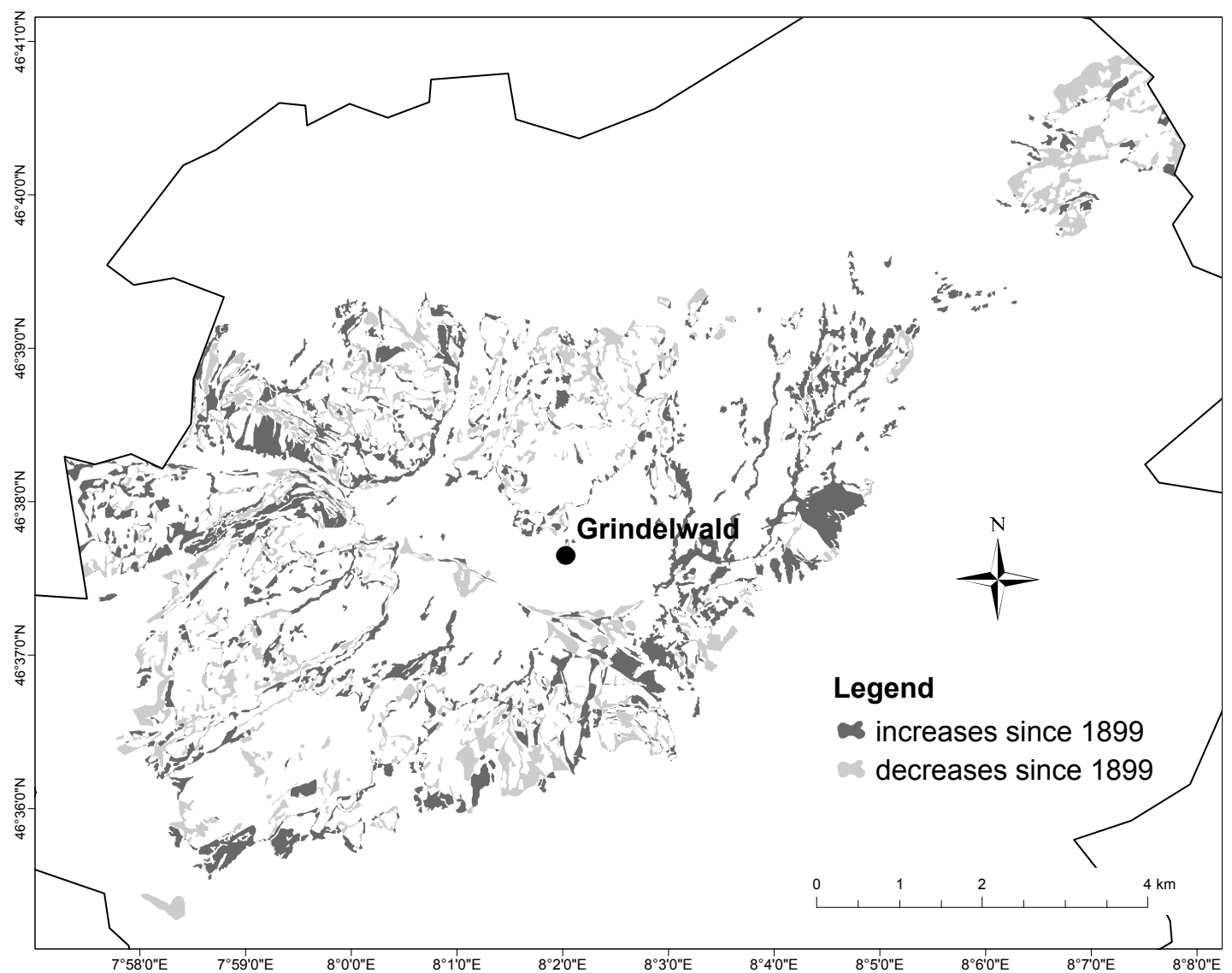

Fig. 3: Forest cover changes in the study area surrounding Grindelwald between 1899 and 2005 Waldveränderungen im Untersuchungsgebiet um Grindelwald zwischen 1899 und 2005

Changements de la couverture forestière dans la zone de recherche autour de Grindelwald entre 1899 et 2005

Cartography: T. Providoli

statistical calculations and queries. The aim of this GIS analysis was to identify the proportion of forest cover change, especially increases in altitude, that can be directly attributed to increasing temperatures. This temperature sensitive zone was defined as the area with the topmost increases of the closed forest cover. In contrast, increases in forest cover below the 1899 forest cover line were attributed to land use change or a change in the disturbance regime.

\section{Results and discussion}

\subsection{Forest cover increase}

The result of the GIS analysis (Fig. 3 and Tables 1 and 2) shows that forest cover in Grindelwald has increased from 1824 ha in 1899 to 2042 ha in 2005. The net growth of 218 ha results from an increase of 695 ha and a loss of 477 ha. Areas with forest cover increase and decrease are distributed across the entire municipal territory. Along the alpine borderline ecotone, increases (210 ha) and decreases (201 ha) are almost balanced, suggesting that forest cover has stagnated despite global warming. A main reason for this limited change is the continuing agricultural use which includes a compulsory and regular clearing of sapling by the farmers on the communal alpine grazing area (Tiefenbach \& Mordasini 2006). Only one area, the biggest of all showing forest expansion (46 ha), can be attributed to climate change. This area is situated in front of the Upper Grindelwald glacier (Fig. 4). The glacier retreated by $220 \mathrm{~m}$ during the last century (EID- 


\begin{tabular}{|c|c|c|c|c|c|c|c|}
\hline & Area (ha) & & Area (ha) & & Area (ha) & & $\begin{array}{l}\text { Area } \\
\text { (ha) }\end{array}$ \\
\hline 1 & 45.97510 & 50 & 0.77761 & 99 & 0.21142 & 148 & 0.04227 \\
\hline 2 & 12.57504 & 51 & 0.74738 & 100 & 0.20917 & 149 & 0.04115 \\
\hline 3 & 11.63731 & 52 & 0.71433 & 101 & 0.20811 & 150 & 0.03989 \\
\hline 4 & 9.05367 & 53 & 0.71054 & 102 & 0.20577 & 151 & 0.03985 \\
\hline 5 & 7.56830 & 54 & 0.66939 & 103 & 0.20464 & 152 & 0.03780 \\
\hline 6 & 7.12141 & 55 & 0.65594 & 104 & 0.20330 & 153 & 0.03721 \\
\hline 7 & 6.61607 & 56 & 0.65437 & 105 & 0.19759 & 154 & 0.03605 \\
\hline 8 & 6.33065 & 57 & 0.60710 & 106 & 0.19519 & 155 & 0.03590 \\
\hline 9 & 6.30460 & 58 & 0.60037 & 107 & 0.19465 & 156 & 0.03421 \\
\hline 10 & 5.24604 & 59 & 0.57432 & 108 & 0.19066 & 157 & 0.03375 \\
\hline 11 & 5.19031 & 60 & 0.53710 & 109 & 0.19016 & 158 & 0.03083 \\
\hline 12 & 4.13380 & 61 & 0.52983 & 110 & 0.18921 & 159 & 0.02848 \\
\hline 13 & 3.87452 & 62 & 0.52912 & 111 & 0.18185 & 160 & 0.02680 \\
\hline 14 & 3.48072 & 63 & 0.51731 & 112 & 0.18083 & 161 & 0.02660 \\
\hline 15 & 2.78413 & 64 & 0.51571 & 113 & 0.17886 & 162 & 0.02363 \\
\hline 16 & 2.48973 & 65 & 0.50551 & 114 & 0.17518 & 163 & 0.02103 \\
\hline 17 & 2.43463 & 66 & 0.45709 & 115 & 0.17372 & 164 & 0.02080 \\
\hline 18 & 2.32294 & 67 & 0.43465 & 116 & 0.17213 & 165 & 0.01966 \\
\hline 19 & 2.21104 & 68 & 0.42360 & 117 & 0.16978 & 166 & 0.01893 \\
\hline 20 & 2.11891 & 69 & 0.41275 & 118 & 0.16171 & 167 & 0.01775 \\
\hline 21 & 1.62933 & 70 & 0.38899 & 119 & 0.15741 & 168 & 0.01231 \\
\hline 22 & 1.60805 & 71 & 0.38419 & 120 & 0.15432 & 169 & 0.01092 \\
\hline 23 & 1.45437 & 72 & 0.37377 & 121 & 0.15294 & 170 & 0.00891 \\
\hline 24 & 1.43946 & 73 & 0.37303 & 122 & 0.15241 & 171 & 0.00721 \\
\hline 25 & 1.42400 & 74 & 0.35707 & 123 & 0.15077 & 172 & 0.00645 \\
\hline 26 & 1.41140 & 75 & 0.35601 & 124 & 0.14221 & 173 & 0.00622 \\
\hline 27 & 1.28748 & 76 & 0.34841 & 125 & 0.14168 & 174 & 0.00580 \\
\hline 28 & 1.27380 & 77 & 0.34823 & 126 & 0.14047 & 175 & 0.00508 \\
\hline 29 & 1.24425 & 78 & 0.34779 & 127 & 0.13937 & 176 & 0.00423 \\
\hline 30 & 1.23688 & 79 & 0.34662 & 128 & 0.13268 & 177 & 0.00409 \\
\hline 31 & 1.11482 & 80 & 0.33901 & 129 & 0.13022 & 178 & 0.00404 \\
\hline 32 & 1.07425 & 81 & 0.33777 & 130 & 0.12919 & 179 & 0.00291 \\
\hline 33 & 1.06239 & 82 & 0.33419 & 131 & 0.12470 & 180 & 0.00244 \\
\hline 34 & 1.05306 & 83 & 0.33150 & 132 & 0.12095 & 181 & 0.00189 \\
\hline 35 & 0.98028 & 84 & 0.32585 & 133 & 0.11781 & 182 & 0.00161 \\
\hline 36 & 0.97020 & 85 & 0.32126 & 134 & 0.11576 & 183 & 0.00150 \\
\hline 37 & 0.97020 & 86 & 0.31805 & 135 & 0.11084 & 184 & 0.00150 \\
\hline 38 & 0.95849 & 87 & 0.31442 & 136 & 0.10903 & 185 & 0.00115 \\
\hline 39 & 0.95217 & 88 & 0.31324 & 137 & 0.10800 & 186 & 0.00112 \\
\hline 40 & 0.94164 & 89 & 0.30983 & 138 & 0.10368 & 187 & 0.00099 \\
\hline 41 & 0.93820 & 90 & 0.29234 & 139 & 0.09980 & 188 & 0.00060 \\
\hline 42 & 0.93038 & 91 & 0.29202 & 140 & 0.08966 & 189 & 0.00051 \\
\hline 43 & 0.91181 & 92 & 0.27123 & 141 & 0.08277 & 190 & 0.00050 \\
\hline 44 & 0.90825 & 93 & 0.25569 & 142 & 0.08234 & 191 & 0.00034 \\
\hline 45 & 0.85245 & 94 & 0.24799 & 143 & 0.07710 & 192 & 0.00030 \\
\hline 46 & 0.85193 & 95 & 0.24694 & 144 & 0.07682 & 193 & 0.00006 \\
\hline 47 & 0.85058 & 96 & 0.23068 & 145 & 0.07261 & 194 & 0.00004 \\
\hline 48 & 0.80647 & 97 & 0.21610 & 146 & 0.06403 & 195 & $3^{*} 10^{-7}$ \\
\hline 49 & 0.80109 & 98 & 0.21544 & 147 & 0.06307 & 196 & $2.7^{*} 10^{-7}$ \\
\hline
\end{tabular}

Tab. 1: Patches of forest cover increase in the borderline ecotone by area

Zunahmen der Waldbedeckung im Waldgrenzökoton, nach deren Grösse sortiert

Croissance de la couverture forestière dans l'écotone, selon la surface 


\begin{tabular}{|c|c|c|c|c|c|c|c|}
\hline & Area (ha) & & Area (ha) & & Area (ha) & & $\begin{array}{l}\text { Area } \\
\text { (ha) }\end{array}$ \\
\hline 1 & 23.21635 & 30 & 1.06302 & 59 & 0.24850 & 88 & 0.02720 \\
\hline 2 & 23.05262 & 31 & 1.05376 & 60 & 0.20048 & 89 & 0.02041 \\
\hline 3 & 17.17451 & 32 & 0.97105 & 61 & 0.19103 & 90 & 0.01992 \\
\hline 4 & 13.11803 & 33 & 0.92611 & 62 & 0.18881 & 91 & 0.01576 \\
\hline 5 & 11.08666 & 34 & 0.79584 & 63 & 0.15942 & 92 & 0.01309 \\
\hline 6 & 8.82423 & 35 & 0.76538 & 64 & 0.15900 & 93 & 0.01229 \\
\hline 7 & 8.74351 & 36 & 0.74018 & 65 & 0.13867 & 94 & 0.01175 \\
\hline 8 & 7.59829 & 37 & 0.73737 & 66 & 0.12861 & 95 & 0.01116 \\
\hline 9 & 7.40652 & 38 & 0.73647 & 67 & 0.11980 & 96 & 0.00736 \\
\hline 10 & 6.33086 & 39 & 0.72971 & 68 & 0.11397 & 97 & 0.00566 \\
\hline 11 & 5.49984 & 40 & 0.71539 & 69 & 0.10583 & 98 & 0.00466 \\
\hline 12 & 4.40611 & 41 & 0.69206 & 70 & 0.10499 & 99 & 0.00396 \\
\hline 13 & 4.29131 & 42 & 0.67267 & 71 & 0.09084 & 100 & 0.00306 \\
\hline 14 & 4.24143 & 43 & 0.62156 & 72 & 0.07945 & 101 & 0.00305 \\
\hline 15 & 4.04407 & 44 & 0.60890 & 73 & 0.07917 & 102 & 0.00196 \\
\hline 16 & 3.42923 & 45 & 0.54774 & 74 & 0.07297 & 103 & 0.00149 \\
\hline 17 & 3.23637 & 46 & 0.46476 & 75 & 0.07220 & 104 & 0.00119 \\
\hline 18 & 3.22801 & 47 & 0.41924 & 76 & 0.06909 & 105 & 0.00111 \\
\hline 19 & 2.78706 & 48 & 0.41476 & 77 & 0.06702 & 106 & 0.00111 \\
\hline 20 & 2.58648 & 49 & 0.35090 & 78 & 0.06526 & 107 & 0.00098 \\
\hline 21 & 2.56720 & 50 & 0.34663 & 79 & 0.06225 & 108 & 0.00064 \\
\hline 22 & 2.22639 & 51 & 0.32409 & 80 & 0.05452 & 109 & 0.00041 \\
\hline 23 & 2.20444 & 52 & 0.30949 & 81 & 0.05450 & 110 & 0.00038 \\
\hline 24 & 1.87192 & 53 & 0.30583 & 82 & 0.04507 & 111 & 0.00029 \\
\hline 25 & 1.82282 & 54 & 0.30066 & 83 & 0.04439 & 112 & 0.00028 \\
\hline 26 & 1.78599 & 55 & 0.28005 & 84 & 0.03960 & 113 & 0.00022 \\
\hline 27 & 1.58173 & 56 & 0.26889 & 85 & 0.03287 & 114 & 0.00020 \\
\hline 28 & 1.48517 & 57 & 0.26683 & 86 & 0.03113 & 115 & 0.00010 \\
\hline 29 & 1.14291 & 58 & 0.26661 & 87 & 0.02782 & & \\
\hline
\end{tabular}

Tab. 2: Patches of forest cover decrease in the borderline ecotone by area Abnahmen der Waldbedeckung im Waldgrenzökoton, nach deren Grösse sortiert Diminution de la couverture forestière dans l'écotone, selon la surface

GENÖSSISCHE TECHNISCHE HochsChUle - ETH ZÜRICH 2010). The newly ice-free area was initially covered by single shrubs and trees, but some sections have already developed into closed forest. Due to the proximity to the glacier and the remote location, the land was not used for grazing (KUPFER 2009).

The new forest in front of the Upper Grindelwald glacier represents only $22 \%$ of the increase in forest cover along the alpine borderline ecotone and only $6.6 \%$ of the entire forest cover increase in the Grindelwald area. These results, while limited, indicate that the postulated increase in alpine forest cover as a consequence of global warming is balanced by the effects of other human activities which affect vegetation directly. Several large areas with increasing forest cover below the 1899 borderline ecotones ( 36 ha, corresponding to $17 \%$ of forest cover increase) confirm this observation. Here, the steepness of the slopes appears to limit the use as meadows leading to land abandonment and reforestation (see areas 2, 4, 5 and 6 in Table 1).

\subsection{Forest cover decreases}

The largest decreases in forest cover in the Grindelwald area appear to be caused by human activities associated with agriculture, road construction and skiing facilities. The relevance of agriculture and maintenance of cultivated mountain pastures are illustrated 


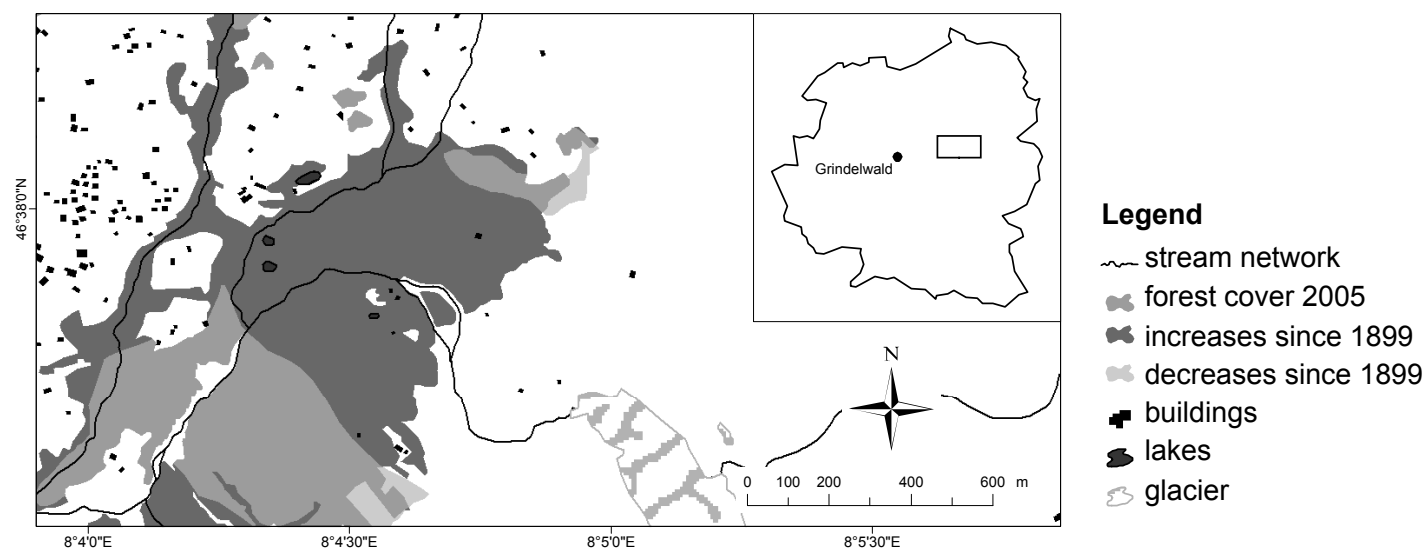

Fig. 4: Forest cover increase between 1899 and 2005 in front of the Upper Grindelwald glacier that was caused by climate warming (area: $45.98 \mathrm{ha}$ )

Zunahme der Waldbedeckung im Vorfeld des oberen Grindelwaldgletschers zwischen 1899 und 2005 (Fläche: 45.98 ha)

Croissance de la couverture forestière autour du glacier supérieur de Grindelwald entre 1899 et 2005 (surface: 45,98 ha)

Cartography: T. Providoli

by the comparatively small changes of vegetation between 1899 and 2005 in regions where alpine meadows are situated next to forest. Along such borders forest increased, for example, on areas 5 and 10 (see Table 1) by only 12.82 ha and decreased on areas 9 and 26 (see Table 2 ) by only 9.2 ha.

The effects of tourism and the general development of rural infrastructure on forest cover are often related to road construction. The road across the Grosse Scheidegg towards Meiringen on Figure 5 illustrates this process: in 1899, a fairly narrow mule-track crossed the forest where today a wide street, suitable even for buses dissects the forest. Overall, the GIS analysis indicates that 43.05 ha of forest in the borderline ecotone were destroyed for road construction between 1899 and 2005. Destruction of forests for skiing is limited in Grindelwald because most tracks are situated above the forest and narrow into small tracks along existing roads to the stations below. In two areas (4 and 5 in Table 2) the forest was removed for skiing tracks $(24.21 \mathrm{ha})$. In one area $(7.6 \mathrm{ha})$ forest has been destroyed because of the construction of a skiing lift (Fig. 6 and area 8 in Table 2).

Natural hazards such as avalanches, landslides, debris flows and rock falls are common around Grindelwald. They represent a further process causing at least temporary forest destruction. These events have a low frequency, but a high magnitude with regards to the disturbance or destruction of trees. They are also not independent of climate. Figure 7 shows a scene at the Eiger North Face where avalanches occurred in 1975, 1984, 1985 and 2003 (AMT FÜR WALD DES KANTONS BERN 2009). Periodic and frequent rock falls and debris flows can also limit the forest cover at a level far below the climatological limit of tree growth (Fig. 8).

\section{Conclusion}

Global warming is often associated with an increase of forest cover in mountain areas. This assumption considers the biophysical limit of tree growth as the dominant factor for the location of the uppermost altitudinal or latitudinal forest cover (KöRNER 2003). While this assumption is valid on a global scale, other factors, such as land use and the ecologic disturbance regime may affect the forest cover in alpine areas. Aim of this study was the identification of the proportion of forest cover change increase in the 20th century that can be attributed directly to global warming in the northern central Alps around Grindelwald, Switzerland. On average, 1933 ha were covered by forest in the study area. Overall, forest cover increased between 1899 and 2005 by 218 ha. Only $21 \%$ of this change can be attributed to global warming, in particular the retreat of the Upper Grindelwald glacier. All other increases are below the 1899 borderline ecotone and thus can not be caused directly by global warming. It is note- 


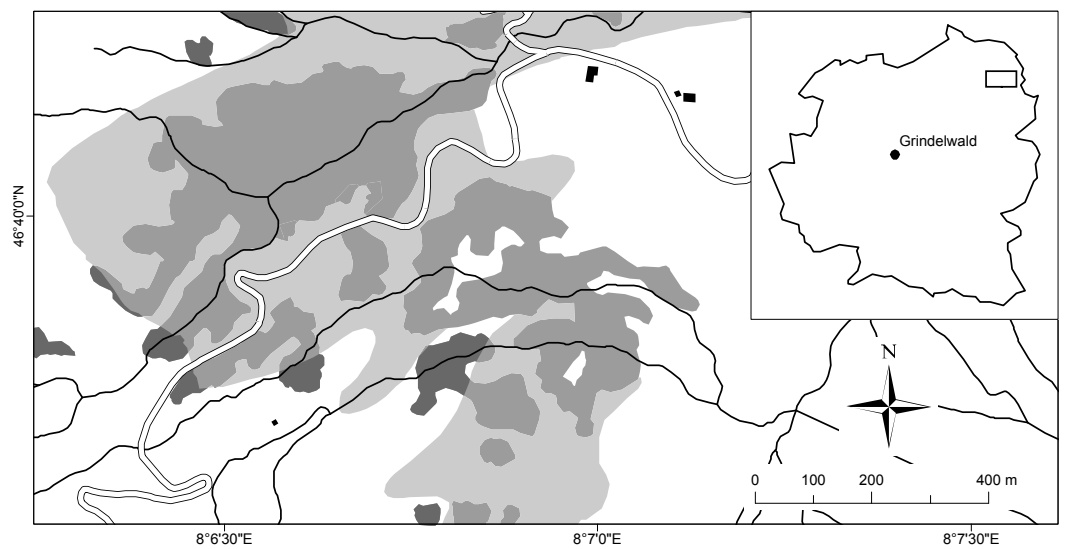

\section{Legend}

m stream network

= streets

forest cover 2005

increases since 1899

decreases since 1899

buildings

Fig. 5: Forest cover decrease that was influenced by human activity: road construction (area: 8.74 ha) Abnahme der Waldbedeckung, die durch menschlichen Einfluss verursacht wurde: Strassenbau (Fläche: 8.74 ha) Diminution de la couverture forestière due à l'activité humaine: construction de routes (surface: 8,74 ha) Cartography: T. Providoli

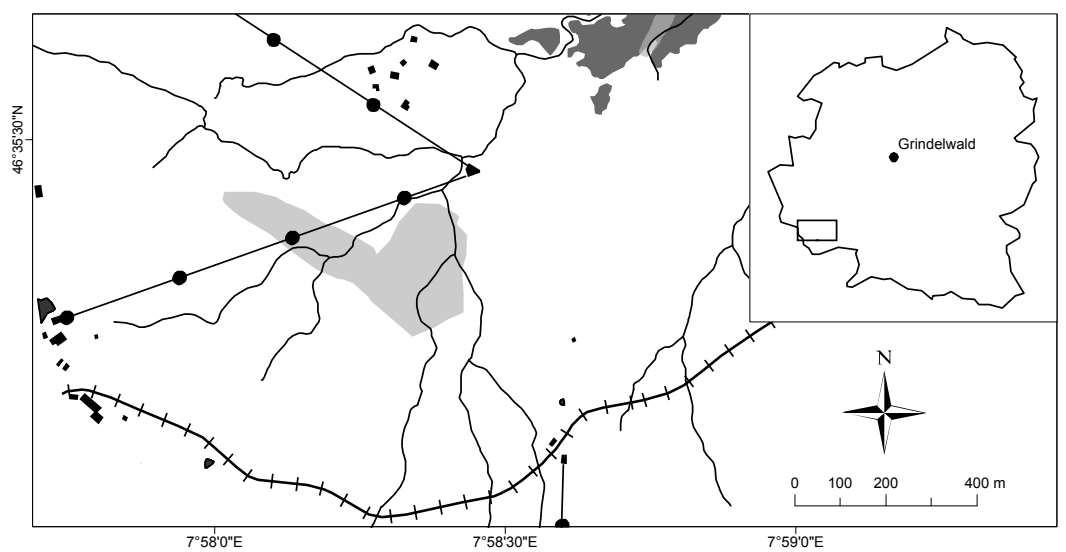

\section{Legend}

m stream network

+ railway

- aerial passenger line u forest cover 2005

* increases since 1899

os decreases since 1899 buildings

$\Omega$ lakes

Fig. 6: Forest cover decrease that was influenced by human activity: ski tourism, mountain pasture (area: 7.6 ha) Abnahme der Waldbedeckung, die durch menschlichen Einfluss verursacht wurde: Skitourismus, Alpweidebewirtschaftung (Fläche: 7.6 ha)

Diminution de la couverture forestière due à l'activité humaine: ski, exploitation des pâturages alpins (surface: 7,6 ha)

Cartography: T. Providoli

worthy that the forest cover results from the difference between a 477 ha decrease and a 695 ha increase. Decrease and increase correspond to $25 \%$ and $36 \%$, respectively, of the average forest cover, indicating that a comparatively large part of the original forest was affected by change. The origin of this change in Grindelwald are largely human activities associated with changes in land use type and intensity. An additional trigger for temporary forest cover change are surface processes such as mass wasting and avalanches, which are not independent of climate, but act rather as a disturbance, acting against an expansion of forest cover. The results of the study presented here indicate that a relatively small area has experienced an 


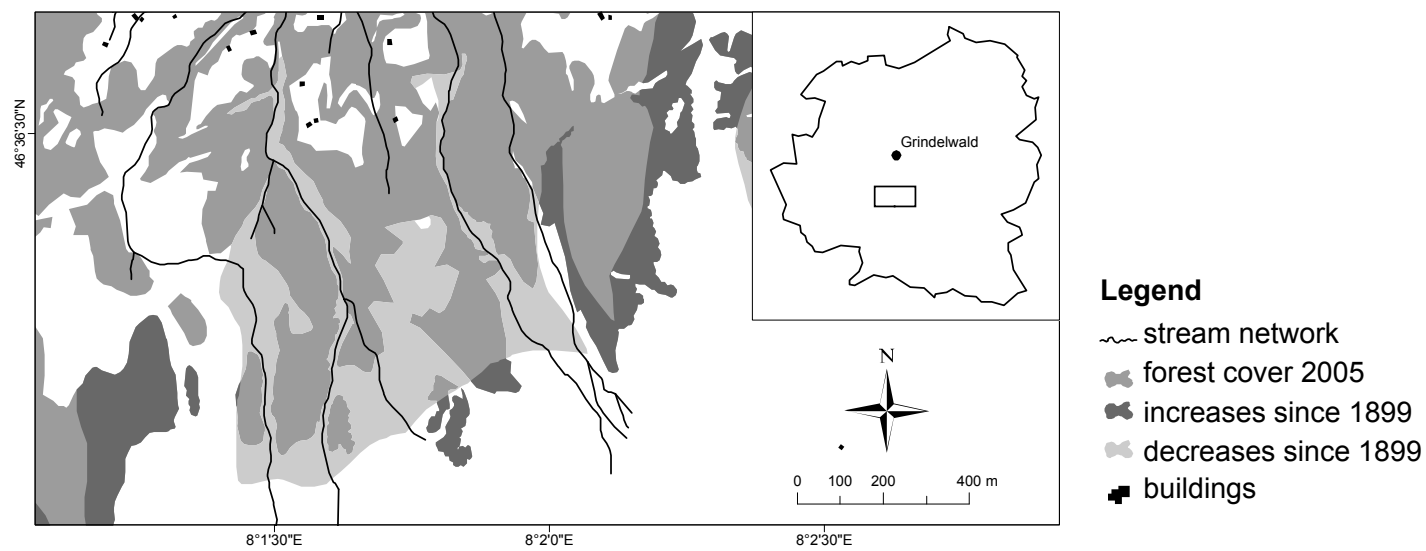

Fig. 7: Forest cover decrease that was influenced by avalanches (area: 17.17 ha) Abnahme der Waldbedeckung, die von Lawinen beeinflusst worden ist (Fläche: 17.17 ha) Diminution de la couverture forestière due aux avalanches (surface: 17,17 ha) Cartography: T. Providoli

increase in forest cover in Grindelwald due to global warming and that land use appears to dominate the extent of the forest along the border to cultivated alpine pastures. As a consequence, agricultural policy and the rural economy will probably act as a strong non-proximate force of change (BAUR et al. 2005) compared to the effects of global warming. Changes in the disturbance regime, such as the location, frequency and magnitude of avalanches and mass wasting, but also fire (ZumbrunNen et al. 2011), may also affect forest cover and counteract increases in altitude. It may therefore be concluded that forest cover change in alpine landscapes under intense human use will occur in a patchwork-like pattern across the current borderline ecotone, determined by the local combination of micro-climate, disturbance and land use.

\section{References}

AMt Für Wald des Kantons Bern (KAWA), Abteilung Naturgefahren (2009): Ereignis- und Lawinenkataster (as shapefile with date of avalanche events recorded in attribute table).

Anisimov, O.A., Vaughan, D.G., Callaghan, T.V., Furgal, C., Marchant, H., Prowse, T.D., VILHJÁlmsson, H. \& J.E. Walsh (2007): Polar regions (Arctic and Antarctic). - In: PARrY, M.L., CAnZIani, O.F., Palutikof, J.P., van der Linden, P.J. \& C.E. Hanson (eds): Climate change 2007: impacts, adaptation and vulnerability. Contribution of Working Group II to the Fourth Assessment Report of the Intergovernmental Panel on Climate Change. - Cambridge: Cambridge University Press: 653-685.
Baur, P., Gellrich, M. \& P. Bebi (2005): Die Rückkehr des Waldes als Wohlstandsphänomen. - In: Bündner Wald 4: 57-61.

Dobbertin, M. \& A. Giuggiola (2006): Baumwachstum und erhöhte Temperaturen. - In: Forum für Wissen: 35-45.

EIDGENÖSSISCHE TeCHNISCHE HoCHCHULE - ETH ZÜRICH (2010): Schweizerisches Gletschermessnetz. Oberer Grindelwaldgletscher, Grindelwald (BE). - URL: http:/glaciology.ethz.ch/messnetz/glaciers/obgrindelwald.html 23.08.2011.

Ewald, K.C. \& G. Klaus (2010): Die ausgewechselte Landschaft. Vom Umgang der Schweiz mit ihrer wichtigsten natürlichen Ressource. $-2^{\text {nd }}$ edition, Bern, Stuttgart, Wien: Haupt Verlag.

Gehrig-Fasel, J., Guisan, A. \& N.E. Zimmermann (2007): Tree line shifts in the Swiss Alps: climate change or land abandonment? - In: Journal of Vegetation Science 18, 4: 571-582.

Gellrich, M., Baur, P., Кoch, B. \& N.E. ZimmermanN (2007): Agricultural land abandonment and natural forest re-growth in the Swiss mountains: a spatially explicit economic analysis. - In: Agriculture, Ecosystems and Environment 118, 1-4: 93-108.

Holtmeier, F.-K. \& G. Broll (2007): Treeline advance - driving processes and adverse factors. - In: Landscape Online. The Official Journal of the International Association for Landscape Ecology: 1-33. URL: http:// www.landscapeonline.de/archive/2007/1/ 20.07.2009. Intergovernmental Panel on Climate Change - IPCC, Solomon, S., Qin, D., Manning, M., Marquis, M., Averyt, K., Tignor, M., Miller, Jr., H.L. \& Z. Chen (eds) (2007): Climate change 2007. The physical sci- 


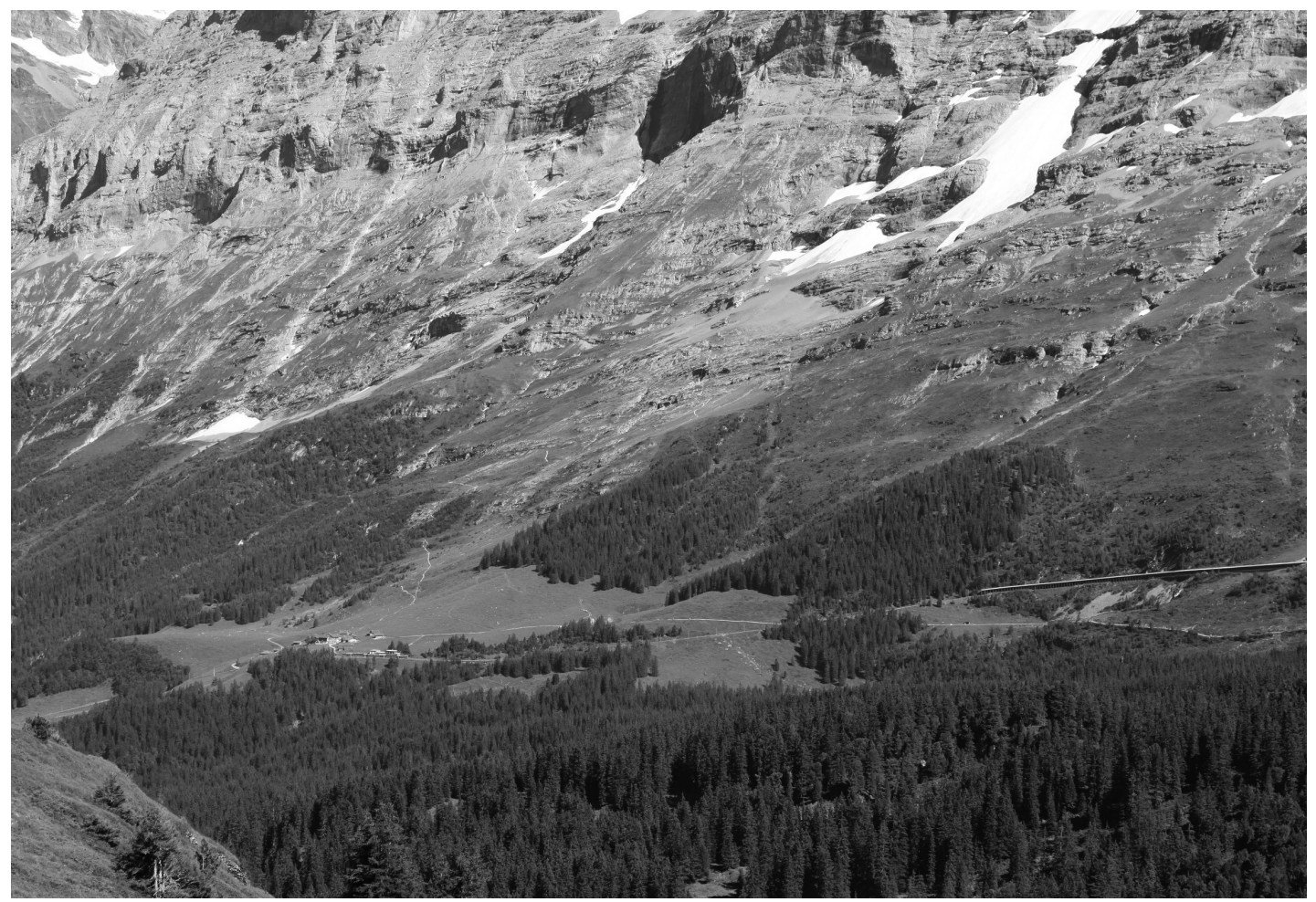

Fig. 8: Talus slope (center), avalanche track (upper right) and debris flow channels (right and left) at the eastern base of the Eiger north face illustrating the effect of surface processes for forest cover in alpine areas. Schutthänge (Mitte), Lawinenbahnen (rechts oben) und Murgangkanäle (rechts und links) an der östlichen Basis der Eigernordwand zeigen den Effekt von Oberfächenprozessen auf die Waldbedeckung in alpinen Gebieten. Déblais rocheux (au milieu), couloirs d'avalanche (en haut à droite) et coulées de boue (à droite et à gauche) à l'est du pied de la face nord de l'Eiger, montrant l'effet des processus de surface sur la couverture forestière de la région alpine.

Photo: N. KuHN

ence basis. Contribution of Working Group I to the Fourth Assessment Report of the Intergovernmental Panel on Climate Change. - Cambridge: Cambridge University Press.

KeARNEY, M.S. \& B.H. LucKMAn (1983): Holocene timberline fluctuations in Jasper National Park, Alberta. - In: Science 221, 4607: 261-263.

KIENHOLZ, H. (1977): Kombinierte geomorphologische Gefahrenkarte 1:10'000 von Grindelwald. - Geographica Bernensia, Vol. G 4, Bern.

Körner, C. (2003): Alpine plant life. Functional plant ecology of high mountain ecosystems. $-2^{\text {nd }}$ edition, Berlin: Springer.

KuPFER, F. (2009): Oberförster Waldabteilung 1 Oberland Ost, Amt für Wald des Kantons Bern (KAWA), personal communication 04.11.09.
Landolt, E. (2003): Unsere Alpenflora. - Frutigen: SAC-Verlag.

LotTer, A.F., Heiri, O., Hofmann, W., van der KnaAp, W.O., van LEeUWEN, J.F.N., WALKer, I.R. \& L. Wick (2006): Holocene timber-line dynamics at Bachalpsee, a lake at $2265 \mathrm{~m}$ a.s.l. in the northern Swiss Alps. - In: Vegetation, History and Archaeobotany 15, 4: 295-307. Macias Fauria, M., Michaletz, S.T. \& E.A. Johnson (2011): Predicting climate change effects on wildfires requires linking processes across scales. - WIREs Climate Change 2, 1: 99-112.

MeteoSwiss - Federal Office of Meteorology and Climatology (2011): Climate today. Trends in Switzerland. - URL: http://www.meteoschweiz.admin.ch/web/ en/climate/climate_today/trends_in_switzerland.html 13.07.2011. 
MeteoSwiss - Federal Office of Meteorology and Climatology (2010): Climap-Net, 25.01.2010.

Meusburger, K. \& C. Alewell (2009): On the influence of temporal change on the validity of landslide susceptibility maps. - Natural Hazards and Earth System Sciences 9: 1495-1507.

NäGELI, R. (1986): Die Berglandwirtschaft und Alpwirtschaft in Grindelwald. Schlussbericht zu Projekt 4.184. - MAB-Programm, Vol. 21, Bern: Bundesamt für Umweltschutz.

North, J. \& M. GuYer (2007): Klimaänderung in der Schweiz. Indikatoren zu Ursachen, Auswirkungen, Massnahmen. Umwelt-Zustand Nr. 0728. - Bern: Bundesamt für Umwelt.

Stampfli, Y.R. (1995): Pflanzengesellschaften der subalpinen und alpinen Stufe in Grindelwald und ihre ökologischen Bedingungen. - Inauguraldissertation der Philosophisch-naturwissenschaftlichen Fakultät der Universität Bern, Systematisch-Geobotanisches Institut..

Tiefenbach, M. \& A.G. Mordasini (2006): Bergschaften in Grindelwald. Alppflege zwischen Tradition und Moderne. - Grindelwald: Sutter Druck.

Van der Meer, M., Hagedorn, F., Schweingruber, F.H., Rigling, A. \& P.A. Moiseev (2004): Dynamik der alpinen Waldgrenze im südlichen Ural (Russland). In: Die Erde 135, 2: 151-174.

Walther, G.-R., Beissner, S. \& R. Ротt (2005): Climate change and high mountain vegetation shifts. - In: Broll, G. \& B. Keplin (eds): Mountain ecosystems. Studies in treeline ecology. - Berlin, Heidelberg: Springer: 77-96.

WiESER, G. \& M. TAUSZ (2007): Current concepts for treelife limitation at the upper timberline. - In: WIESER, G. \& M. TAusz (eds): Trees at their upper limit. Treelife limitation at the alpine timberline. - Plant Ecophysiology, Vol. 5, Dordrecht: 1-18.

Zumbrunnen, T., Pezzatti, G.B., Menendez, P., BugMANN, H., BÜRgI, M. \& M. CONEDERA (2011): Weather and human impacts on forest fires: 100 years of fire history in two climatic regions of Switzerland. - In: Forest Ecology and Management 261:2188-2199.

\section{Abstract: Climate and land use effects on forest cover in the Bernese Alps during the 20th century}

In this study changes in the forest cover in the municipality of Grindelwald between 1899 and 2005 was analyzed. The aim was to identify whether global warming has an effect on forest cover on a regional scale in an intensely used alpine landscape. By comparing the area of forest mapped on the Siegfried map of 1899 with the current forest using ArcGIS, positive and negative changes could be detected and geo-referenced. In the forest borderline ecotone, which would be sensitive to climate change, an increase of 210 ha and a decrease of 201 ha was measured. This corre- sponds to approximately $10 \%$ of the forest cover in Grindelwald. The balanced change in cover indicates that the forest borderline ecotone did not change very strongly during the 20th century. This can be explained by the intensive alpine agriculture of the region above the tree line. The alpine farmers tend mountain pastures by clearing saplings. Only a single large increase (46 ha) in front of the retreating Upper Grindelwald glacier can be attributed to global warming. Other smaller increases occurred where agricultural land has been abandoned, mostly below the 1899 tree line and thus not attributable to climate change. Decreases in forest cover can be attributed to human influences, such as expansion of alpine agriculture and tourism (construction of transportation infrastructure) and morphodynamic processes, such as avalanches. It can be concluded that forest cover in Grindelwald is strongly affected by humans. Any changes, therefore, cannot be used as a general indicator for (or against) climate change.

Keywords: forest line, climate indicator, climate warming, agricultural land abandonment, morphodynamic processes

\section{Zusammenfassung: Klima- und Landnutzungseffekte auf die Waldbedeckung im Berner Oberland während des 20. Jahrhunderts}

In dieser Studie wurde die Veränderung der Waldgrenze in der Gemeinde Grindelwald zwischen 1899 und 2005 untersucht. Durch die Verschneidung der alten Waldfläche mit der neuen Waldfläche mit Hilfe von ArcGIS konnten alle $\mathrm{Zu}$ - und Abnahmen seit 1899 genau bestimmt werden. Ziel der Studie war eine Abschätzung der Folgen von Klimawandel auf die Waldbedeckung in einer alpinen Kulturlandschaft. Im klimasensiblen Waldgrenzökoton wurden 210 ha Zunahme und 201 ha Abnahme ermittelt. Dies entspricht etwa $10 \%$ der Waldfläche in Grindelwald. Daraus kann geschlossen werden, dass sich die Waldgrenze nicht stark verändert hat. Dies ist auf die intensive alpwirtschaftliche Nutzung der Flächen oberhalb der Waldgrenze durch den Menschen zurückzuführen. Die Bergschaften sorgen durch Ausreissen von jungen Bäumen dafür, dass das Alpgebiet nicht kleiner wird. Eine einzige grossflächige Zunahme (46 ha) konnte der Klimaerwärmung zugeordnet werden. Andere kleinere Zunahmen konnten auf Gebieten verzeichnet werden, wo die alpwirtschaftliche Nutzung aufgegeben wurde. Abnahmen gehen auf menschliche Einflüsse wie Alpwirtschaft und Tourismus (Strassenund Skiliftbau) und morphodynamische Prozesse wie Lawinen zurück. Abschliessend kann festgestellt werden, dass die Waldgrenze in Grindelwald sehr stark vom Menschen beeinflusst wird und Veränderungen nicht als Klimaindikator verwendet werden sollten. 
Schlüsselwörter: Waldgrenze, Klimaindikator, Klimaerwärmung, Aufgabe der alpwirtschaftlichen Nutzung, morphodynamische Prozesse

\section{Résumé: Effets climatiques et effets d'exploitation alpestre sur la forêt de l'Oberland bernois pendant le 20ème siècle}

Cet article étudie les changements auxquels la limite de la forêt de la commune de Grindelwald a été soumise entre 1899 et 2005. En comparant l'ancienne et l'actuelle surface boisée à l'aide du logiciel ArcGIS, il a été possible de déterminer les taux de croissance et de décroissance de la forêt depuis 1899. Une augmentation de 210 ha et une diminution de 201 ha ont été repérées dans l'écotone de la limite forestière. Ces données montrent que le changement de la limite de la forêt est relativement faible, ce qui est dû à l'exploitation alpestre intensive par l'homme au-dessus de la limite de la forêt. En arrachant les jeunes arbres, les troupeaux transhumants contribuent à maintenir les pâturages alpins. Seule la croissance d'une surface boisée assez étendue (46 ha) peut être attribuée au réchauffement climatique. D'autres augmentations de la surface boisée ont été enregistrées dans des zones où l'exploitation agricole a été abandonnée. Les diminutions de la surface forestière sont dues à des activités humaines comme l'exploitation agricole ou le tourisme (construction de routes et de téléskis) ainsi qu'à des processus morphodynamiques comme les avalanches. À Grindelwald, les variations de la limite de la forêt sont donc majoritairement causées par l'homme plutôt que par le réchauffement climatique. Par conséquent, la limite de la forêt ne peut y être conçue comme un indicateur climatique.

Mots-clés: limite de la forêt, indicateur climatique, réchauffement climatique, cessation de l'exploitation agricole, processus morphodynamiques

Tobias Providoli, M.Sc., Federal Office of Topography swisstopo, Seftigenstrasse 264, CH-3084 Wabern, Switzerland.

e-mail: tobias.providoli@swisstopo.ch

Prof. Dr. Nikolaus J. Kuhn, Department of Environmental Sciences, Institute of Geography/Physical Geography and Environmental Change, University of Basel, Klingelbergstrasse 27, CH-4056 Basel, Switzerland.

e-mail: nikolaus.kuhn@unibas.ch

Manuskripteingang/received/manuscrit reçu le 31.8.2011

Annahme zum Druck/accepted for publication/accepté pour publication: 8.5.2012 